\title{
Research-based Teaching Comprehension Strategies: Bridging the Gap
}

\author{
Ndileleni Paulinah Mudzielwana \\ Department of Early Childhood Education, University of Venda, Private Bag x5050, Thohoyandou, 0950, South Africa
}

\begin{abstract}
I present research-based strategies for teaching reading comprehension. In order to read and understand texts, learners must know which strategies to use. Teachers find the teaching of reading comprehension strategies challenging and do not teach it effectively. As a result, learners struggle to read texts with understanding. This article is based on empirical research done on reading comprehension teaching to Grade 3 Tshivenda-speaking learners. The study found that the teaching of reading comprehension strategies depend on the theoretical knowledge of teachers and their practical experience in teaching comprehension.
\end{abstract}

Index Terms - reading comprehension, Grade 3 Tshivenda-speaking learners, comprehension strategies, research-based strategies, mother tongue, foundation phase

\section{INTRODUCTION}

Learners who cannot read and understand texts is a challenge in South Africa (The Progress in International Reading Literacy Study (PIRLS), 2006; The Sunday Times, 2000). A large number of learners who cannot read and understand text are found in the Foundation Phase. This situation is concerning, since the Foundation Phase is the start of education.

There is sufficient evidence supporting the teaching of the strategies of comprehension monitoring, graphic and semantic organisers, question answering, question generating, story structure, summarising and multiple strategies (NRP, 2000). I realised that there is lack of recent empirical research on reading comprehension in rural areas of South Africa. Within the context of my research, based on the low performance of Grade 3 Tshivenda-speaking learners of the Vhembe district in the Limpopo province, there is a need for teachers to teach comprehension strategies to help learners read with understanding.

\section{CONCEPTUAL Platforms OF THE StUdy}

Here I present the reading comprehension strategies based on research evidence identified by the NRP (2000). These theories assisted me in exploring the research-based strategies that were successful in other countries.

\section{A. Piaget's Theory of Cognitive Development}

Piaget (1968) maintains that children use schemes to organise, categorise and understand the world. As children grow older, these schemes become increasingly abstract as new experiences are assimilated into the existing schemes. Piaget states that experiences and interaction with the environment facilitates the development of cognitive structures (Lieberman, Clark, Krone, Orlandi\&Wynder, 1992).

Piaget's (1968) theory has implications for teaching reading comprehension as each child's current stage of cognition development must be taken into account when teachers plan learning activities. Knowledge about this stage will assist teachers understand that learners are ready to listen to stories, and to read stories which move between the past and present and about heroes.

Piaget's theory relates to this study in that learners should construct the meaning of texts in reading comprehension and be able to use it in contexts outside the classroom. Learning activities should match the level of the conceptual development of learners. Teachers must use the stages as a way to gauge and monitor learners' pace of learningand must teach learners to acquire self-regulatory competence by observing and listening to their explanations. Piaget's (1968) view is that learners must be self-initiated and actively involved in learning.

\section{B. Vygotsky's Socio-historical Theory of Cognitive Development}

Vygotsky (1978) attributes cognitive development to the social environment of children and the role of parents. Cognitive development proceeds from behaviours regulated by others to self-regulated behaviour (Zimmerman, 1998). According to Vygotsky, when a child is working independently, we see the actual development level of children. When children are working with an adult, we see the potential development of children. The difference between these two levels of functioning is referred to as the Zone of Proximal Development (ZPD) (Biehler\& Snowman, 1993; Gage \& Berliner, 1992). With regards to the importance of the ZPD, Vygotsky (1978, p. 137-138) emphasises:

Everything that the child cannot do independently, but which he can be taught or which he can do with direction or cooperation or with the help of leading questions, we will include in the sphere of imitation... Thus, in studying what the 
child is capable of doing independently, we study yesterday's development. Studying what the child is capable of doing cooperatively, we ascertain tomorrow's development.

The area of immature, but maturing processes makes up children's ZPD. When children are faced with challenging situations, they can seek help from their teachers and peers, which is termed 'scaffolding' (Woolfolk, 1995).

Vygotsky believes that language is an important tool because it is internalised by children to affect thinking and problem-solving (Bukatko\&Daehner, 2001; Shaffer, 1996). Teachers can focus on effective communication, meaning and comprehension of language. Vygotsky's theory has implications for teaching reading comprehension because in facilitating learning, teachers must take the cultural context of the learners into consideration as it influences their thinking. Learners can be given problem-solving activities with instructions for the task of reading comprehension. Thereafter learners should work independently using their own knowledge and skills with the guidance received from teachers. Two approaches are pertinent to teaching reading comprehension, based on the views of Vygotsky, namely reciprocal teaching and scaffolded support.

\section{Reciprocal teaching}

Palincsar and Brown (1984) developed an approach to teaching reading comprehension called reciprocal teaching. Reciprocal teaching is an instructional procedure to improve learners' comprehension skills and is related to Vygotsky's ZPD and scaffolding. This approach has three main components, namely:

- Dialogue between learners and teacher, each taking turns in the role of dialogue leader;

- Reciprocal interactions, where one person acts in response to another;

- Structured dialogue using four strategies, namely generating own questions, summarising parts of texts, clarifying word meanings and text passages, and predicting what might come next in texts.

The overall goal of reciprocal teaching is to promote self-directed and flexible use of the learnt strategies through scaffolding instruction collaboration (Sporer,Brunstein\&Kieschke, 2009). According to the NRP (2000), the focus of reciprocal teaching is upon the actual teaching approach. Reciprocal teaching involves four instructional procedures for explicitly teaching four strategies, namely summarising, questioning, clarifying and predicting (Palincsar\& Brown, 1984).

In reciprocal teaching, these strategies pertain to ongoing dialogues with a dialogue leader, who can be a teacher or a learner who models the use of the strategies, provides conditional knowledge about strategy use, and helps learners to apply a strategy to a passage. The leader helps the group clarify difficult words or passages that might hinder comprehension. Next, the leader summarises the text read and predicts what might happen next. The process continues for each part of the text, with learners taking turns leading the discussion. In this way, learners are actively involved in their own learning, while poorly self-regulated learners can learn from their highly self-regulated peers.

Teachers can also begin with a group of learners discussing the text. Teachers start by modelling each strategy. The demonstration includes a clear explanation of what the strategy is, a description of how and when to use it, and an explanation of why it is useful for enhancing understanding. After explaining and modelling the strategy, teachers ask learners to read, providing guidance and support (NRP, 2000; Zimmerman, 1998; Shanahan, 2006).

\section{Scaffold support}

Scaffolding involves the provision of support that is focused on learners' particular capacities within ZPD. Teachers take all the responsibility for applying a newly introduced strategy by modelling. Learners must observe, imitate and self-regulate themselves, and create meaning from the text by using the strategy. As learners get more exposure to strategies, teachers withdraw their responsibility. This enables learners to manage their own learning by making use of the strategies. Eventually, learners take more and more responsibility as they become confident, knowledgeable and capable. Finally, they are able to work independently (Pardo, 2004; McMahon \& Oliver, 2003).

\section{Bruner's Theory of Learning and Development}

Bruner (1986) maintains that thinking and reasoning are integrated into a single process. He advocates learning through discovery and active learning, where the problem-solving skills of learners are encouraged. Like Piaget and Vygotsky, Bruner regards social and cultural factors as important in cognitive development (Driscoll, 1994).

With regards to teaching reading comprehension, teachers should present new concepts repeatedly, initially at a simple level and then at an increasingly difficult level, a concept Bruner (1986) referrers to as the "spiral ordering of content."

\section{Ausubel's Cognitive Field Theory}

For meaningful learning to occur, learners must be ready and willing to relate new concepts to their current experience and to what learners already know. Meaningful learning occurs when learners actively process the information they are asked to learn. Ausubel (1963) refers to his theory as "verbal learning," because most of what is learnt in the classroom is based on language as a means of communication. Another concept of Ausubel is "reception learning," where learners receive information, think about it deductively and apply the information. Ausubel believes that learning occurs as a result of the relatedness of what learners know and what they learn.

With regards to teaching reading comprehension, teachers must be aware of the fact that certain minimal levels of intellectual maturity are necessary before various subjects can be taught with efficiency and success. Therefore, teachers 
must consider learners' points of view, and take into account their limitations in the command of language and their grasp of concepts.

\section{E. Bandura's Social Learning Theory}

Bandura (1977) developed a social learning theory in which children use rewards, punishment and imitation to understand the working of the world (Kail, 2001). According to Bandura (1977), the environment plays an important role in children's life, because this is where they interact with other people who act as role models. Children's interaction with other people is based on observing their norms, values and beliefs within the context of a particular society and children are most likely to imitate adults with whom they have an emotional bond, which Bandura (1977) calls "naturant models." Bandura (1977) refers to this concept as "modelling," which means that learners learn behavioural patterns from observing behaviour. When learners interact with people, they adopt and live according to what has been seen (Mwamwenda, 1995).

Bandura states that "experience gives learners a sense of self-efficacy, which refers to learner's beliefs about their own abilities and talents" (Kail, 2001, p. 16). This means that learners will have a good sense of what they can or cannot do and will not imitate the actions of someone if they feel their own abilities are dissimilar. Furthermore, through memory, what is observed must be processed so that it can be retrieved when the information is needed. Observation is important because the behaviour displayed by the model should be reproduced. For an observed behaviour to be reproduced perfectly, practice is important. Reinforcement also plays an important role and if modelled behaviour is rewarded, the chances of this behaviour being repeated are high (Hjelle\& Ziegler, 1981; Engler, 1985).

With regards to reading comprehension, teachers are regarded as good models, as they have positive relationships with learners. They should therefore display positive reading comprehension strategies so that learners can imitate and internalise these.

\section{F. Zimmerman's Applied Social-cognitive Model of Self-regulated Learning}

According to Zimmerman (1998; 1990), self-regulated learning involves the regulation of three general aspects of academic learning, namely:

- Self-regulation of behaviour, involving active controlling of the various resources learners have available to them (Pintrich, Smith, Garcia \& McKenzie, 1993);

- Self-regulation of motivation, involving controlling and changing motivational beliefs so that learners can adapt to the demands of a course;

- Self-regulation of cognition, involving controlling of various cognitive strategies for learning, resulting in better learning and performance (Palincsar\& Brown, 1989; Pintrichet al., 1993).

Teachers must thus motivate learners to be actively involved in reading with understanding instead of memorising words on the page. It is important for teachers to encourage learners to think positively about reading comprehension and believe that they can read and understand texts, and to condition their satisfaction to reach their goals (Zimmerman, 1998). Teachers must teach learners to acquire self-regulatory competence in order to become independent readers. Zimmerman (1998) proposes that learners themselves should be the source of plans, intentions, strategies and emotions that are necessary to create meaning from text. However, the self-regulatory strategy will not work for all learners and using a few strategies will not work on all tasks (Zimmerman, 1998). Zimmerman thus suggests multiple self-regulatory strategies rather than single strategies.

Zimmerman (1998) postulates that the applied social-cognitive model of self-regulated learning can be organised within a learning cycle based on three types of self-effective thoughts:

- Goal-setting and strategic planning;

- Self-monitoring of accuracy in implementing a selected strategy;

- Self-assessment of strategy outcome and task performance.

These processes are considered cyclic because each process entails information that can lead to changes in a subsequent step of the cycle. These processes qualify as self-reflective cognition activities and the associated corrective processes are central features of each step of the cycle (Sporer, et al., 2009).

Drawing on Zimmerman's applied model of self-regulated learning, learners are engaged in cognition and metacognitive activities during reciprocal teaching, and alternate between prompting, using a strategy, applying the selected strategy and monitoring its accurate implementation (Sporer,et al., 2009).

\section{RESEARCH-BASED COMPREHENSION STRATEGIES TO BE TAUGHT TO GRADE 3 LEARNERS}

I reviewed comprehension strategies to be taught to Grade 3 learners. Each is discussed below.

\section{A. Comprehension Monitoring}

The teaching and monitoring of comprehension strategies refers to learners' knowledge about and use of reading comprehension strategies. Routman (2000, p. 134) defines comprehension monitoring as "a metacognitive process which is affected by person strategy and task variables."Comprehensive monitoring is essential for reading, as it directs readers when trying to make sense of texts (Routman, 2000). Good readers use metacognitive strategies to think about 
and have control over their reading, e.g., before reading, they monitor their understanding, adjusting their reading speed to fit the difficulty of the text and 'fix-up' any comprehension problems they have, e.g., identifying where in the text the difficulty occurs, restarting a difficult sentence or passage on their own and looking back through the text (Lehr $\&$ Osborn, 2005).Readers thus learn how to be aware of understanding their material during comprehension monitoring (NRP, 2000). This implies that when learners monitor their comprehension, they understand that reading must make sense, and when it does not they try to use appropriate different fix-up strategies to resolve the problems.

In teaching comprehension monitoring strategies, teachers need to demonstrate awareness of difficulties of understanding words, phrases, clauses or sentences. Learners are taught to think about what is hampering their understanding. They think aloud, reread, slow down, and look back through texts to try to solve a problem (Armbruster,Lehr \& Osborn, 2003).

\section{B. Graphic and Semantic Organisers}

The tools of graphic and semantic organisers enable learners to examine and visually represent relationships, and help learners write well-organised summaries. These organisers illustrate concepts and interrelationships among concepts of text, using pictorial devices (Armbruster\& Osborn, 2003).Graphic and semantic organisers are found in many forms, e.g., semantic maps and graphic metaphors. These allow the reader to represent graphically/visually the meanings and relationships of concepts (Armbruster\& Osborn 2003; Lehr \& Osborn, 2005). Lehr and Osborn (2005) state that graphic and semantic organisers allow readers to represent graphically/visually the meanings and relationships of the ideas that underlie texts and to improve readers' memories of what they read.

In teaching the use of graphic and semantic organisers, teachers must ask learners to construct an image that represents the content.

\section{Questioning}

Questions appear effective for improving learners' reading comprehension as they provide learners with a purpose for reading, help learners to focus attention on what they are to learn, help learners to think actively as they read, encourage learners to monitor their comprehension, andhelp learners to review content and relate what they have learnt to what they already know.

Durkin (1978) critiques asking and answering questions as a reading comprehension strategy, pointing out that the manner in which teachers ask questions is more an assessment of comprehension than the teaching of reading comprehension. However, it is important for teachers to ask various questions to develop learners' critical thinking. Bloom (1968) and Joubert,Bester and Meyer (2008) show that the type of questions learners become accustomed to can shape their understanding of texts, e.g., when learners are constantly asked literal questions, they will focus on these during reading comprehension. Routman (1996) maintains that teachers need to ask higher-order questions and show learners how to find answers. This requires interactive settings in order to achieve high levels of reading comprehension. Analysis by Zimmerman and Hutchins (2003, p. 73) indicates that "questions lead readers deeper into a piece, setting up dialogue with the author, sparking in readers' minds what they care about. If you ask questions as you read, you are awake. You are interacting with words". This implies that questioning during reading becomes a strategy to help learners interact with the author and so remain focused throughout the text. Teachers must ask a combination of questions and show learners how to find answers. This can be done by discussing the different types of questions that exist with learners (Raphael and $\mathrm{Au}, 2005)$ and using the information to locate the answer.

In order to succeed, Taylor, Pearson, Peterson and Rodriguez (2002) and Bloom (1968) state that learners must engage in high levels of questioning and do so in highly interactive settings to achieve high levels of comprehension. Thus, it is critical that instruction helps learners understand that active readers question the author, the text, and themselves before, during and after reading. In order for learners to be able to answer higher-order questions, they need to understand the relationship between the question and the answer, or where to find the answer (Raphael and Au, 2005).

Under questioning as a comprehension strategy, there are two different strategies, namely answering and generating questions. These strategies are discussed separately because the one affects teachers and the other affects the learner.

\section{Question Answering}

During question answering, the reader answers questions posed by teachers and is given feedback for correctness. It gives learners a purpose for reading, focuses attention on what they are to learn, helps them review content and relate what they have learnt to what they already know. Learners learn to distinguish questions that can be answered based on the text from those based on prior knowledge and therefore acquire more knowledge (Armbruster\& Osborn, 2003). There are different types of questions, e.g., one type helps learners understand the relationships between questions and where the answers to those questions are found. In this instruction, readers learn to answer questions that require an understanding of information.

Questioning during the guided reading phase is intended to scaffold learning for learners and to check learners' understanding. Such questioning is intended to instruct, guiding learners to independence (Dewitz, 2006).

When teaching the question answering strategy, teachers need to ask learners questions during and after reading passages. Teachers ask learners to look back, which is when learners articulate and process their understanding of what they have read to find answers after reading. Teachers ask learners to analyse questions with respect to whether the 
question is tapping literal information covered in the text, information that can be inferred by combining information in the text, or information in the reader's prior knowledge base (NRP, 2000).

\section{E. Question Generation}

Question generation encourages learners to be actively, and independently, involved and to become aware of whether they understand texts or not, and thus improves comprehension ability (Routman, 1996; Duke \& Pearson, 2002). In their view, Lehr and Osborn (2005) confirm that teaching learners to ask their own questions improves their active processing of text and improves their comprehension. By generating questions, learners become aware of whether they can answer the questions and whether they understand what they are reading. Learners learn to ask themselves questions that require them to integrate information from different segments of text, e.g., learners can be taught to ask main idea questions that relate to important information in texts.

Question generation also assist learners to increase their awareness of whether they are comprehending text (NRP, 2000; Armbruster\& Osborn, 2003). Questioning can be applied before, during and after reading. Pearson (1985) suggests that during reading comprehension, teachers should ensure that guided reading questions include inference questions to enhance both story-specific inferential comprehension and comprehension of new stories. Also, adding a pre-reading set for evoking relevant prior knowledge and predicting what will happen in a story, coupled with discussion of why it is important to do so, results in better inferential comprehension.

In teaching the question-generating strategy, teachers need to ask learners to generate questions while reading a passage. Teachers should ask learners to evaluate their questions, checking that they covered important material and were integrative. Teachers provide feedback on the quality of the questions asked or assist learners in answering the questions generated (Armbruster\& Osborn, 2003).

\section{F. Story Structure}

During reading comprehension, the reader continuously asks questions in order to understand the text. The story structure is "the way the content and events of a story are organised into a plot" (Lehr \& Osborn, 2005, p. 18). This is where readers ask themselves questions about various aspects of the story (NRP, 2000). Lehr and Osborn (2005) also state that learners who recognise the story structure have greater appreciation; understanding and memory of texts.Instruction in the content and organisation of stories improve learners' comprehension and memory of stories. These strategies train learners to ask questions during reading about the basic components of stories. Learners learn to identify the categories of content, such as setting, initiating events and outcomes, and how this is organised into a plot (Lehr \& Osborn, 2005).

Thus, during the teaching of reading comprehension, teachers need to ask and answer five questions:

- Who is the main character?

-Where and when does the story occur?

- What does the main character do?

- How does the story end?

- How does the main character feel?

This helps learners identify what happened and what was done in the story, e.g., they recognise the story structure through the use of story maps, i.e., recording the setting, problem, goal, action and outcome (Armbruster\& Osborn, 2003). A type of graphic organiser thus shows the sequence of events in stories.

\section{G. Summarising}

Summarising requires learners to determine what is important in what they read, to condense information and to rephrase in their own words (Ambruster\& Osborn, 2003). Routman (2000) refers to summarising as the ability to state the main ideas in texts in a clear and coherent manner. This involves paraphrasing and reorganising text information. It requires readers to sift through large units of text, differentiating important from unimportant, and significant from insignificant ideas (Armbruster\& Osborn, 2005).Thereafter they synthesise those ideas and create a new coherent text that stands for the original (Dole, Duffy, Roehler\& Pearson, 1999).

Klinger and Vaughn (1999) and the NRP (2000) maintain that summarisation can be taught effectively and that the ability to summarise can improve comprehension recall. However, "summarising sounds difficult and the research demonstrates that ... it is" (Dole et al., 1999, p. 244).Teachers, therefore, need to give learners opportunities to practice summarisation before they apply it. Summarising will enable learners to process texts more deeply and better retain their knowledge of texts. In teaching summarising as a strategy, teachers need to teach learners to summarise main ideas and leave out the less important aspects.

\section{RESEARCh DESIGN AND METHOdOLOGY}

The data presented in this article is derived from a larger research project undertaken, where a case study was employed. The unit of analysis was three schools in the Dzindi Circuit, Vhembe District, Limpopo Province, South Africa. I selected this specific case purposefully (Merriam, 1998) and aimed to investigate the teaching of reading comprehension to Grade 3 Tshivenda-speaking learners. Despite the recommended changes to Curriculum 2005 (DoE, 
C2005) to develop an improved curriculum for the $21^{\text {st }}$ century, South Africa still faces reading literacy problems at the Foundation Phase (DoE, 2008). Concerns about learners' development of basic literacy skills at the foundation levels of education (Bloch, 1999; Lessing \& De Witt, 2005) are consistently reflected in local and international research (Fleisch, 2008; SAQMEC, 2004; Howie, Venter, Van Staden, Zimmerman, Long, Scherman\& Archer, 2006).

Teachers and learners of the case study speak Tshivenda as a mother tongue, and Tshivenda is the language of teaching and learning in the schools. Not all Grade 3 learners and teachers at the schools of the Vhembe district were included in the study. However, those who executed the study claim an approach to enquiry that was qualitative and subjective in nature (Merriam, 1998). We assumed that teachers' experiences and understanding were real and should be taken seriously by other teachers. We documented the voices of teachers through individual and focus group interviews, and classroom observations. We used a variety of data collection instruments to obtain rich data in our attempt to answer our research question (May, 2002). Table 1 provides a summary of the methods and instruments that were used for data collection, as well as the data capturing method/s.

\begin{tabular}{|c|c|c|c|c|}
\hline $\begin{array}{l}\text { Methods of } \\
\text { data collection }\end{array}$ & Type & $\begin{array}{l}\text { Instrument assisting } \\
\text { data collection }\end{array}$ & Prompt & $\begin{array}{l}\text { Data capturing } \\
\text { method }\end{array}$ \\
\hline Interview & $\begin{array}{l}\text { Individual } \\
\text { interview }\end{array}$ & $\begin{array}{l}\text { Researcher interviewing } \\
\text { teachers; } \\
\text { Interview schedule }\end{array}$ & $\begin{array}{l}\text { Discussion about teaching reading } \\
\text { comprehension to Tshivenda- } \\
\text { speaking learners and their } \\
\text { experiences as teachers }\end{array}$ & $\begin{array}{l}\text { Informal field } \\
\text { notes; } \\
\text { Audio tape } \\
\text { transcription of } \\
\text { interviews }\end{array}$ \\
\hline $\begin{array}{l}\text { Focus group } \\
\text { interviews }\end{array}$ & Small group discussions & $\begin{array}{l}\text { Researcher involving } \\
\text { teachers in discussions; } \\
\text { Researcher asking } \\
\text { questions }\end{array}$ & $\begin{array}{l}\text { Discussion about the teaching of } \\
\text { reading comprehension to } \\
\text { Tshivenda-speaking learners and the } \\
\text { experiences as teachers }\end{array}$ & $\begin{array}{l}\text { Focus group } \\
\text { discussion } \\
\text { schedule; } \\
\text { Transcription of } \\
\text { discussions; } \\
\text { Audio tape / } \\
\text { informal field } \\
\text { notes }\end{array}$ \\
\hline Observation & $\begin{array}{l}\text { Classroom } \\
\text { observation }\end{array}$ & $\begin{array}{l}\text { Researcher observations; } \\
\text { Observation schedule }\end{array}$ & None. Used 'natural field setting' & $\begin{array}{l}\text { Informal field } \\
\text { notes }\end{array}$ \\
\hline $\begin{array}{l}\text { Content } \\
\text { analysis }\end{array}$ & $\begin{array}{l}\text { Official policy documents } \\
\text { with provision for } \\
\text { teaching reading } \\
\text { comprehension }\end{array}$ & $\begin{array}{l}\text { Researcher collecting } \\
\text { policies }\end{array}$ & $\begin{array}{l}\text { Discussion about teaching reading } \\
\text { comprehension to Tshivenda- } \\
\text { speaking learners as explained in } \\
\text { policy documents }\end{array}$ & $\begin{array}{l}\text { Researcher } \\
\text { reviewing } \\
\text { literature; } \\
\text { Grounded theory; } \\
\text { Thematic analysis }\end{array}$ \\
\hline
\end{tabular}

\section{RESEARCH FINDINGS AND DISCUSSIONS}

Participating teachers were asked questions as one means of data collection. Here I present only teachers' responses from question 2: Which strategies do teachers use to teach reading comprehension? The responses were categorised as Theme 2. The data was derived from the various instruments used to collect empirical data. Theme 2 states: one who is teaching reading comprehension must be ready to teach and must know his/her learners.

Classroom observation was also executed, the objective being to determine whether what teachers said about the teaching of reading comprehension was actually taking place.

A strategy is "instructional mental actions during reading that improve reading comprehension", deliberate efforts by a reader to better understand or remember what is being (Shanahan, 2006). It is critical that teachers know strategies and apply them in their classrooms. However, the participating teachers showed a lack of knowledge about teaching reading comprehension strategies during classroom observations.

The following remarks from teachers were representative:

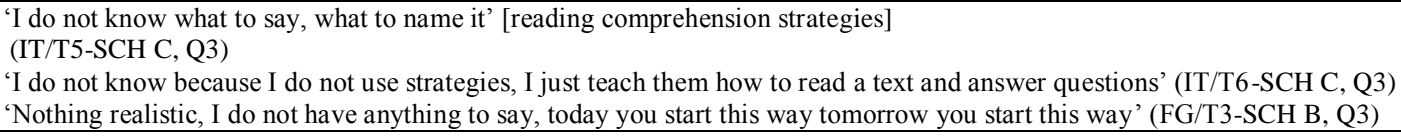

'I do not know because I do not use strategies, I just teach them how to read a text and answer questions' (IT/T6-SCH C, Q3)

'Nothing realistic, I do not have anything to say, today you start this way tomorrow you start this way' (FG/T3-SCH B, Q3)

During reading comprehension, teachers must provide a clear explanation of the structure of the strategy to be learnt and explain why strategies are used (Ben-Ari \&Kedem-Frederich, 2000; McEwan, 2004). Palincsar and Brown (1984), Trabasso and Bouchard (2002) and Henk, Moore, Marinak, and Tomasetti (2000) suggest that teachers should have knowledge of multiple strategies. In my understanding, if the participating teachers had the knowledge base, they would have taught the learners how to read with understanding. However, teachers showed that they did not have a theoretical knowledge of comprehension strategies.

Participating teachers expressed different views when asked about which strategies they use in teaching reading comprehension. Learners should learn to use these strategies before, during and after reading texts in order to selfregulate their own learning (Schunk\& Zimmerman, 1994; Zimmerman, 1998; Keene \& Zimmerman, 1997; Puustinen\&Pulkkinen, 2001). Pre-reading activities are essential to prevent learners from 'barking at print' (Wessels, 
2010). This implies that teachers must teach the importance of pre-reading activities and their use for enhancing reading comprehension. During classroom observations, teachers asked learners to preview texts and talk amongst themselves, and make predictions. However, during classroom observations it was not found that teachers told learners why they should preview the text before they started with the actual reading of the text. Additionally, the most commonly used strategy was to discuss the illustrations. Talking about illustrations is important because it can create the desire to read a book (Wessels, 2010). What was not observed were teachers linking the predictions made during the pre-reading phase with the content.

This was highlighted by teachers in the following way:

'Time is offered to children to can guess what will happen in the story' (FG/T1-SCH A, Q 3)
'They can predict what will happen' (FG/T5-SCH C, Q 3)
'Learners predict what will happen in the story' (IT/T4-SCH B, Q 3)

The guided reading phase was not evident during classroom observations. The term 'guided' implies a structure that is first modelled to learners by teachers, then practised with learners and eventually demonstrated by the learners themselves (Flynt\&Cooter, 2005). There were few learners asked to read individually during reading lessons. In most cases it was only the ones who could read and not the struggling readers that were asked. During the interviews, teachers said that learners could not read and understand texts:

'Children cannot read and write' (IT/T1-SCH A, Q1)

'There are many challenges especially those children who cannot read and understand' (FG/T5-SCH C, Q3)

Literature confirms that primary grade teachers fail to teach learners strategies for becoming proficient readers (Harvey \&Goudvis, 2007; Shanahan, 2006). Teachers should thus be supported to do so. In addition, Ivy and Fisher (2007) state that educators are flooding the professional learning community with requests for strategies that work to improve the teaching of reading comprehension.

Asking questions to learners or learners asking questions is an important strategy for teaching reading comprehension (Parkey \& Hurry, 2007). During classroom observations, questions were asked frequently. Teachers preferred to ask learners questions, but the learners struggle to give the correct answers because they cannot read and understand texts. The following responses from teachers illustrate the point:

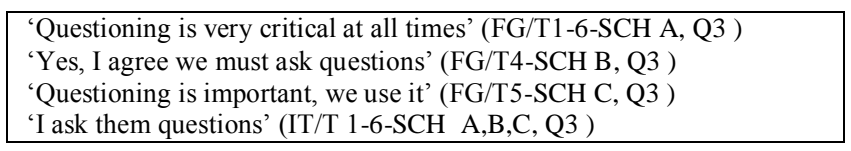

From these responses it is clear that teachers prefer to ask learners questions. However, most of the questions are at a literal level, possibly because most learners cannot read and understand the words. The teachers said that they are not aware of comprehension strategies, that they regard teaching comprehension as a challenge and that they are frustrated because they have learners who cannot read and understand texts. McNeil (1992), Miller (2002), and Reynolds and Brown (2001) suggest that the use of strategy is beneficial for reading comprehension. Williams (2007, p. 40) says the following:

A rationale for teaching comprehension strategies is that readers derive more meaning from text when they engage in intentional thinking. That is when people run into difficulties in understanding what they have read; the application of specific strategic cognitive processes will improve their comprehension.

Durkin (1979) finds that teachers concentrate more on asking questions instead of teaching how to comprehend texts. This may be due to the lack of teachers' knowledge about the use of reading comprehension strategies. What I noticed was that because of the lack of understanding, learners fail to answer higher-order questions. Surprisingly, teachers did not ask learners to generate questions about the text themselves. Also, no evidence was found that teachers encourage learners to use 'fix-up' strategies.

During interviews, respondents indicated that they preferred to start reading comprehension lessons by asking learners to learn the difficult words.

'I can start by explaining difficult words' (FG/T3-SCH B, Q3)

'Learners underline the new difficult words' (IT/T1-SCH A, Q3)

literature agrees that teaching learners the meaning of difficult words is an important reading comprehension strategy because learners already know the words by the time they read the text (Armbruster\& Osborn, 2003). Cain, Oakhill and Bryant (2004) state that decoding skills may predict the ability of reading comprehension in children.

With regard to the after-reading phase of teaching, teachers asked learners to read aloud and to retell what they had read. Teachers reminded learners to concentrate on major events or to summarise. However, there was no evidence of teachers' asking learners to read sections of the text that substantiated answers to questions they had made and to confirm or disprove predictions they had made based on prior knowledge. I conclude that the absence of these aspects may be due to teachers' lack of knowledge about the importance of reading comprehension strategies. 
With regard to modelling strategies, data revealed limited evidence of teachers modelling strategies, e.g., when asked which strategies they use in teaching reading comprehension during interviews, a teacher confirmed that she did not know what to name the strategy. Wessels (2010) emphasise that it is important for teachers to model good behaviour of reading and the strategies before reading so that learners may use them during independent reading and when they experience problems. Also, the importance of modelling strategies is that learners get opportunities to learn and see how strategies should be incorporated by watching expert comprehenders modelling the strategies (Miller, 2002). It is therefore necessary that teachers be competent, since they are required to model and practice a given strategy (Pressley, 2002). Only one teacher indicated what she did before the start of reading comprehension:

'I explain to the learners what to do like what must be done, why the strategy helps and demonstrate how they can apply the strategy independently' (IT/T5-SCH C, Q 3)

No evidence was found of the following:

- where the pace and flow of the various phases of reading comprehension lessons represented an effective use of strategies;

- teachers' encouraging learners to use strategies;

- teachers' modelling during the teaching of comprehension strategies.

Reasons for the absence of modelling may be teachers' lack of theoretical knowledge about the concept of teaching learners' comprehension strategies, as well as not being given opportunities to observe an expert teaching reading comprehension in Tshivenda.

Literature reveals that comprehension strategies should be taught and learnt (Farrell, 2001; NRP, 2000; Durkin, 1993; Myers, 2005). Blachowicz and Ogle (2001), Ambruster and Lehr (2001), and Harvey and Goudvis (2000) agree that in order to prevent reading comprehension difficulties, teachers should teach learners reading comprehension strategies. Consequently, teachers will develop a positive attitude towards their work and learners will read the words and understand what they are reading. However, the teaching of reading comprehension is a challenge, as expressed by teachers during the interviews.

Participants lacked knowledge of the concept of self-regulated learning as described by Zimmerman (1998). No respondents indicated any process for supporting learners. They did not indicate any skill they taught that would enable learners to control their own learning. They did not realise that learners could self-regulate their learning through acquiring specific strategies. The knowledge of Zimmerman's (1998) applied social cognitive model of self-regulated learning is needed to account for the low level of reading comprehension amongst the learners of this research study. The model suggests that learners must be actively involved in their own learning. Therefore, it is important that teachers should put them into practice in their teaching. Then, as learners become capable of choosing and using strategies, teachers may gradually hand over the responsibility to the learners (Zimmerman, 1998).

During the interviews, teachers complained about the little time given for teaching reading as indicated in the policy document Teaching Reading in Early Grades (DoE, 2008):

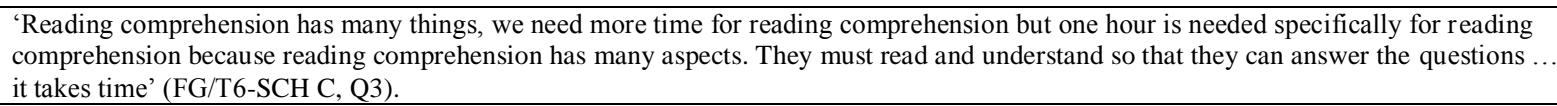

Teachers indicated that time for reading should be increased since reading comprehension was a challenge to them. This confirms that teachers are acutely aware of time pressures to meet objectives within the literacy hour. They say that when such teachers are under pressure, they tend to use a more directive form of teaching with less emphasis on active learning, which in turn influences the teaching of reading comprehension negatively.

During interviews teachers highlighted their challenges, concerns and frustrations:

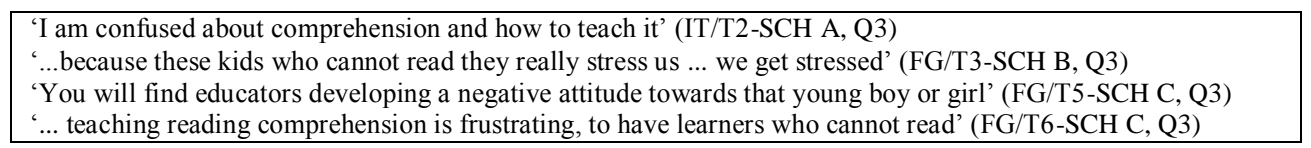

It thus becomes clear that teachers are aware that there are learners in their classrooms who cannot read and understand and this creates stress and frustrations. This was indicated during interviews, and was confirmed in classroom observations. I failed to find evidence about teachers' teaching strategies to learners. In essence, it was not clear if teachers knew what they should do when planning reading comprehension and their roles in teaching learners to read texts with understanding.

\section{CONCLUSION}

There is agreement that teaching reading comprehension can enhance learners' understanding of texts. There are research-based comprehension strategies which teachers must know and model during reading. Teachers must monitor learners' understanding and ensure that they use strategies correctly. 
Teachers should organise their comprehension teaching in the following stages to help learners understand the importance and the correct use of strategies:

- Before teaching comprehension, teachers must examine texts for rigour, level of questioning and vocabulary.

- Before reading they must teach learners to set a purpose for reading, provide questions and connections to motivate learners, pre-teach key vocabulary concepts, relate texts to learners' lives and teach learners' text features.

- During reading, teachers must deepen learners' level of understanding by modelling text reading.

- They must provide multiple opportunities for learners to read and interact with the text. It is important during reading to deepen learners understanding by asking them questions at various levels. Teachers must also teach learners to generate questions.

- After teaching, teachers must be able to reflect on learners' responses to instruction and plan for deeper teaching opportunities.

Teachers have a pivotal role to play in preparing learners for independent learning. Capacity building for teachers is therefore needed, with appropriate guidelines on how to teach reading comprehension. The comprehension strategies reviewed in this article will help learners to read texts with understanding.

\section{REFERENCES}

[1] Armbruster, B.B., Lehr, F. \& Osborn, J. (2003). Kindergarten through to Grade 3: Put Reading First: The Research Building Blocks of Reading Instruction: Kindergarten to Grade3. Washington DC: National Institute for Literacy.

[2] Ausubel, D.P. (1963). The Psychology of Meaningful Verbal Learning. New York: Bruner \& Stratton.

[3] Bandura, A. (1977). Social Learning Theory. Englewood Cliffs: Prentice Hall.

[4] Ben-Ari, R. \& Kedem-Friedrich, P. (2000). Restructuring Heterogenous Classes for Cognitive Development Social Interactive Perspective. Instructional Science, 28(2): 153-167.

[5] Biehler, R.F. \& Snowman, J. (1993). Psychology Applied to Teaching. Boston: Houghton Mifflin.

[6] Blachowicz, C. \& Ogle, D. (2001). Reading Comprehension: Strategies for Independent Learners. New York: The Guilford Press.

[7] Bloch, C. (1999). Literacy in the Early Years: Teaching and Learning in Multilingual Early Childhood Classrooms. International Journal of Early Years Education, 7(1):39-51.

[8] Bloom, B.S. (1968). Learning Mastery. Evaluation Comment, 1 (2): 1-12.

[9] Bruner, J. (1986). Actual Minds: Possible Worlds. Cambridge: Harvard University.

[10] Bukatko, D.\&Daehler, M.W. (2001). Child Development: A Thematic Approach. Boston: Houghton Mifflin.

[11] Cain, K., Oakhill, J. \& Bryant, P. (2004). Children's Reading Comprehension Ability: Concurrent Prediction by Working Memory, Verbal Ability, and Component Skills. Journal of Educational Psychology, 96:31-42.

[12] Department of Education (DoE) (2008). Foundations for Learning Campaign (FFLC).Government Gazette, 513: pages 1-25.

[13] Dewitz,P. (2006). Reading Comprehension in Five Basal Reading Programs. Los Angeles. Paper Presented at the Annual Meeting of the National Reading Conference.

[14] Dole, J.A., Duffy, G.G., Roehler, L. \& Pearson, P.D. (1999). Moving from the Old to the New: Research on Reading Comprehension Instruction. Review of Educational Research, 61:239-264.

[15] Driscoll, M.P. (1994). Psychology of Learning for Instruction. Needham Heights: Allyn \& Bacon.

[16] Duke, N.K. \& Pearson, P.D. (2002). Effective Practices for Developing Reading Comprehension. In A.E. Farstup \& S.J. Samuels (Eds.). What Research has to Say about Reading Instruction ( ${ }^{\text {rd }}$ ed.). Newark: International Reading Association, 205242.

[17] Durkin, D. (1978). What Classroom Observations Reveal about Reading Comprehension. Reading Research Quarterly, 16:515-544.

[18] Durkin, D. (1979). What Classroom Observations Reveal about Reading Comprehension Instruction. Reading Research Quarterly, 14(4):481-533.

[19] Durkin, D. (1993). Teaching them to Read (6 ${ }^{\text {th }}$ ed). Needham: Allyn and Bacon.

[20] Farrell, T.S.C. (2001). Teaching reading strategies: "It takes time!" Reading in a Foreign Language, 13(2): 631-646.

[21] Flynt, E.S.,\&Cooter, R.B. (Jr.) (2005). Improving Middle-Grades Reading in Urban Schools: The Memphis Comprehension Framework. Issues in Urban Literacy. The Reading Teacher, 58(8): 774-780.

[22] Harvey, S. \& Goudvis, A. (2007). Strategies that Work: Teaching Reading Comprehension for Understanding and Engagement $\left(2^{\text {nd }}\right.$ ed). Portland: Sternhouse.

[23] Henk, W.A., Moore, J.C., Marinak, B.A. \& Tomasetti, B. (2000). A Reading Lesson Observation Framework for Elementary Teachers, Principals, and Literacy Supervisors. The Reading Teacher, 53(5):358-369.

[24] Hjelle, L.A. \& Ziegler, D. J. (1981). Personality Theories Basis Assumptions, Research and Application. Auckland: McGraw Hill

[25] Howie, S.J., Venter, E., Van Staden, S., Zimmerman, L., Long, C., Scherman, V.\& Archer, E. (2007). PIRLS 2006 Summary Report: South African Children's Reading Achievement. Pretoria: University of Pretoria, Centre for Evaluation and Assessment.

[26] Ivy, G. \& Fisher, D. (2005). Learning from what Doesn't Work. Educational Leadership, 63(2):8-40.

[27] Joubert, I., Bester, M. \& Meyer, E. (2008). Literacy in the Foundation Phase. Pretoria: Van Schaik.

[28] Kail, R.V. (2001.) Children and their Development ( $2^{\text {nd }}$ Ed). Upper Saddle River: Prentice-Hall.

[29] Keene, E. \& Zimmerman, S. (1997). Mosaic of Thought. Portsmouth: Heinemann.

[30] Klinger, J.K. \& Vaughn, S. (1999). Promoting Reading Comprehension, Content Learning and English Acquisition through Collaborative Strategic Reading (CSR). The Reading Teacher, 52(7):738-747. 
[31] Lehr, F. \& Osborn, J. (2005). Focus on Reading Comprehension. Available Online: www.prel.org/programs/rel/rel.asp. Accessed 12.11.2011.

[32] Lessing, A.C. \& De Witt, M.W. (2005). Teaching Reading in an OBE Framework. Pretoria: University of South Africa.

[33] Lieberman, L.D., Clark, N.M., Krone, K.V., Orlandi, M.A.\&Wynder, E.L. (1992). The Relationship between Cognitive Maturity and Information about Health Problems among School Age Children. Health Education Research, 7(3): $391-401$.

[34] May, T. (2002). Qualitative Research in Action. London: Sage.

[35] McEwan, E.K. (2004). 7 Strategies of Highly Effective Readers. California: Corwin.

[36] McMahon, M. \& Oliver, R. (2003). Self-Regulated Learning. In C. McNaught \& D. Lassner (Eds.). Proceedings of Ed-Media 2003. 2464-2470.

[37] McNeil, J.D. (1992). Reading Comprehension. New Directions for Classroom Practice ( $3^{\text {rd }}$ Ed). New York: Harper Collins.

[38] Merriam,S.B. (1998). Qualitative Research in Practice. Examples for Discussion and Analysis. San Francisco: Jossey-Bass.

[39] Miller, D. (2002). Reading with Meaning: Teaching Comprehension in the Primary Grades. Portland: Stenhouse.

[40] Mwamwenda, T.S. (1995). Educational Psychology: An African Perspective. Durban: Butterworth.

[41] Myers, P.A. (2005). The Princess Storyteller, Clara Clarifier, Quincy Questioner, and the Wizard: Reciprocal Teaching Adapted for Kindergarten Students. The Reading Teacher, 59(4): 314-324.

[42] National Reading Panel (NRP) (2000). Teaching Children to Read: An Evidence-Based Assessment of the Scientific Research Literature on Reading and its Implications for Reading Instruction. Washington DC: National Institute of Child Health and Human Development.

[43] Oczkus, L. (2004). Super 6 Comprehension Strategies. Norwood: Christopher Gordon.

[44] Palincsar, A.S. \& Brown, A.L. (1984). Reciprocal Teaching in Comprehension Fostering and Monitoring Activities. Cognition and Instruction, 1(2): 117-175.

[45] Pardo, L.S. (2004). What Every Teacher Needs to Know about Comprehension. The Reading Teacher, 58(3): 274-279.

[46] Parkey, M and Hurry, J (2007). Teachers' use of Questioning and Modelling Comprehension Skills in Primary Classrooms. Educational Review.59 (3):299-314.

[47] Pearson, P.D. (1985). Changing the Face of Reading Comprehension Instruction. The Reading Teacher, 38(8):724-738.

[48] Piaget, J. (1953). The Origin of Intelligence in the Child. London: Routledge \& Kegan Paul.

[49] Pintrich, P.R., Smith, D., Garcia, T., \& Mckeachie, W. (1993). Predictive Validity and Reliability of the Motivated Strategies for Learning Questionnaire (MSLQ). Educational and Psychological Measurement, 53: 801-813.

[50] Pressley, M. (2002). Reading Instruction that Works: the Case for Balanced Teaching ( ${ }^{\text {nd }}$ Ed). New York: Guilford.

[51] Puustinen, M. \& Pulkkinen, L. (2001). Models of Self-Regulated Learning: A Review. Scandinavian Journal of Educational Research, 45:269-286.

[52] RAND Reading Study Group. (2002). Reading for Understanding: Toward an R \& D Program in Reading Comprehension. Santa Monica: RAND Corporation.

[53] Reynolds, R. \& Brown, K.J. (2001). Reading Teacher Empowerment through Knowledge: The Role of Cooperative Masters Programs in Professional Development. Manuscript under Publication.

[54] Routman, R. (2000). Conversations: Strategies for Teaching, Leaning and Evaluation. Portsmouth: Heinemann.

[55] Routman, R. (1996). Literacy at the Cross Roads: Crucial Talk about Reading, Writing, and other Teaching Dilemmas. Portsmouth: Heinemann.

[56] Shaffer, D.R. (1996). Developmental Psychology: Childhood and Adolescence. California: Brooks/Cole.

[57] Shanahan, T. (2006). The National Reading Panel Report: Practical Advice for Teachers. Chicago: University of Illinois, Learning Point Associates.

[58] Sporer, N., Brunstein, J.C., \& Kieschke, U. (2009). Improving Students' Reading Comprehension Skills: Effects of Strategy Instruction and Reciprocal Teaching. Learning and Instruction, 19: 272-286.

[59] Taylor, B.M., Pearson, P.D., Peterson, D. \& Rodriguez, M.C. (2002). Looking Inside Classrooms Reflecting on the "How" as well as the "What" in Effective Reading Instruction. The Reading Teacher, 6(3): 270-279.

[60] The Sunday Times. (2000). SA Pupils are the Dunces of Africa. 16 July 2000, (p.1).

[61] Trabasso, T. \& Bouchard, E. (2002). Teaching Readers How to Comprehend Text Strategically. In C.C. Block \& M. Pressley (Eds.).Comprehension Instruction: Research Based Best Practices. USA: Guilford, 179-200.

[62] Vygotsky, L.L. (1978). Mind in Society. The Development of Higher Psychological Processes. Harvard: Harvard University.

[63] Wessels, M. (2010). Practical Guide to Facilitating Language Learning ( ${ }^{\text {rd }}$ Ed). Southern Africa: Oxford University.

[64] Williams, T.L. (2007). Reading the Painting: Exploring Visual Literacy in the Primary Grades. International Reading Association, 60(7), 636-642.

[65] Woolfolk, A.E. (1995). Educational Psychology $\left(6^{\text {th }}\right.$ Ed). Boston: Prentice- Hall.

[66] Zimmerman, B.J. (1990). Self-regulated Academic Learning and Achievement: The Emergence of a Social Cognitive Perspective. Educational Psychology Review, 2:173-201.

[67] Zimmerman, B.J. (1998). Academic Studying and Development of Personal Skill: A Self-Regulatory Perspective. Educational Psychologist, 33:73-86.

[68] Zimmerman, S. \& Hutchins, C. (2003). 7 Keys to Comprehension. New York: Random House.

[69] Raphael, T. \& Au, K. (2005). QAR: Enhancing Comprehension and Test-taking Across Grades and Content Areas. The Reading Teacher, 59(3):206-221.

[70] The Progress in International Reading Literacy Study (PIRLS) (2006). Online Available: http://nces.ed.gov/survey/pirls/index.asp. Accessed: 4.03.2009.

[71] Schunk, D.H. \& Zimmerman, B.J. (1994). Self-Regulation of Learning and Performance: Issues and Educational Implications. Hillsdale: Erlbaum. 
Ndileleni Paulinah Mudzielwana is a lecturer of Literacy in the Department of Early Childhood Education at University of Venda, South Africa. She received her BA, BEd from University of Venda and her MEd in Early Childhood Education from Melbourne, Australian Catholic University. Her interests include project-based teaching, small group teaching, cooperative learning, self-regulated learning, and teaching reading in early childhood education. 